On the outskirts of a village in the mountains of Chiapas a man in a torn white woolen chamarra chops down young trees with his machete, chops the dead wood into bundles \& tethers the end with pieces of hemp. The man, his wife \& son tie the bundles to their tumplines, fit the wide bands to their foreheads \& before dawn set out over the mountains. The sun comes up. It's ten when they reach town but late afternoon when they finally sell the three bundles of firewood for a few pesos to a house, say, of North American anthropology students. How pleased they are to be rid of that load! They hunker in the grass in the park or in the street in front of the church, eat some tortillas \& beans, \& start out for home. They trot. It's a long way. I have friends who've started out for that village \& had to turn back.

ii.

At night the North American anthropology students sit around the fireplace with a few beers, projecting the ecological tragedy of the denuded forests of Chiapas \& discussing the price of hand-made leather goods on Guadalupe Street. A blonde girl with drooping breasts who has taken to parading about the streets in Indian clothing tosses another log on the fire.

\title{
iii.
}

The man, his wife \& son reach the outskirts of their village. It's dark \& cold. There are no stars.

$$
\text { iv. }
$$

In the house of the anthropologists the fresh wood crackles for a moment like gunfire.

\section{The Poor}

One point of view is that the poor are less unfortunate than our guilt leads us to imagine. What one lacks in material comforts one gains by a carefree disposition, a healthy physicality, a simpler \& more sensuous, earthier life. At this point the rich, excessive laughter of the Black will be cited. Furthermore, it is always possible, according to this opinion, for the exceptional man, under whatever social handicap, to rise above his station, the 
corollary of which opinion is that it is for each man to make himself exceptional.

The other point of view is that this is not the case at all, \& that such talk is only a pleasant way to amuse oneself in the evening, to bring a flush to one's cheeks, while at the same time reminding one's companions that we too, after all, are self-made men, \& by thus arguing to share in the fellowship of agreeable conversation after a fine meal in an excellent resturant, where one has been made talkative by a strong \& expensive wine.

\section{-- Steve Kowit}

Brooklyn NY

\section{our song}

the sirens are always going around

here, it's number one

on the hit parade, and

here are some words that

might fit,

whenever I hear a siren I know it's

our song at

8 in the morning, 3 a.m., midnight and noon it's

garbage disposal day trash day laundry day

sanitary civilization

they even pick up

the tombstone sellers the morticians the doctors

and the nurses and the orderlies,

the living and the dying and the dead,

those ambulance sirens

they are always going around here,

you know, there's junk enough for all of us:

used bottles, used clothes, used cars, used

houses, used women, used newspapers, used

people,

some day we'1l clear the whole earth of it,

let it go,

red lights off, sirens stopped,

who needs the dismal madness of

everything quitting

again and again? ... falling stars, stinking seals, torn stockings, the whole

Christmas tree assassinated duck

heritage .... 